\title{
The Advocacy Model of Indonesian Chinese Students, the Affluent Market
}

\section{Leonnard}

Sekolah Tinggi Manajemen IPMI, Jakarta, Indonesia, leonnard.ong@ipmi.ac.id

Yulita Fairina Susanti

Sekolah Tinggi Manajemen IPMI, Jakarta, Indonesia, yulita.susanti@ipmi.ac.id

\begin{abstract}
Increasing demand for education services and supply in the number of higher education institutions in Indonesia, both local and foreign universities require private universities to build, improve and sustain their competitiveness. Among others, Indonesian Chinese students are considered as the main consumers of most private universities in Indonesia. The purpose of this study is to investigate the advocacy model of Indonesian Chinese students at private universities Jakarta. A causal design survey was applied out of 250 Indonesian Chinese students. The data were analysed by using the Structural Equation Modelling (SEM) and Lisrel 8.8 software package. The findings revealed that there were positive influences of trust $(\beta=0.640)$ and service quality $(\beta=0.270)$ on advocacy. The influence of trust as a mediating variable increased the total effect of service quality on advocacy $(\beta=$ $0.590)$. Furthermore, service quality $(\beta=0.510)$ and image $(\beta=0.470)$ were also known to be positively influencing trust. The finding will help managers and leaders of private universities to understand the significant effect of certain factors, especially trust on the advocacy of their students. To improve student trust, the university must maintain and improve the service quality offered.
\end{abstract}

Keywords: advocacy, image, quality, SEM, trust, advocacy model

\section{INTRODUCTION}

Universities have gone through many changes since the late 20th century. Universities are no longer seen only as providers of education services, but also as business ventures. Increasing supply of higher education institutions leads to growing alternatives available to students, which then generate a high competition. This circumstance requires universities to improve and to sustain competitive advantages to be able to compete in those highly competitive academic environments. Each university attempts to attract and to retain students in order to maintain the institution and to gain over competitors. The question of how universities manage their consumer advocacy is one of the most important issues in the higher education market. Student advocacy is a very important

Citation: Leonnard, \& Susanti, Y. F. (2019). The Advocacy Model of Indonesian Chinese Students, the Affluent Market. International Journal of Instruction, 12(1), 625-640. https://doi.org/10.29333/iji.2019.12140a 
factor in building a competitive advantage in the industries (Bharadwaj, Varadarajan, \& Fahy, 1993).

There were limited studies have been carried out in term of advocacy models in educational institutions, particularly in universities. Several studies have analyzed the impacts of behavioral segmentation on student's loyalty (Susilo, 2016), the impact of cocreation on the loyalty (Giner \& Peralt Rillo, 2016), satisfaction levels of university students (Alemu \& Cordier, 2017; Arif, Ilyas, \& Hameed, 2013; Bryła, 2015; Cheok \& Wong, 2015; Daryanto, Sukandar, \& Yusuf, 2013; El-Said \& Fathy, 2015; Zedda, Bernardelli, \& Maran, 2017), the factors affect student satisfaction, image and loyalty (Hussain, Rahman, Zaheer, \& Saleem, 2016; Pandey \& Deshwal, 2018; Weerasinghe \& Fernando, 2018). Other studies discuss the model of universities 'service qualities (Abdullah \& Mohamad, 2016; Chui, Ahmad, Bassim, \& Zaimi, 2016; Gobena, 2018; Sultan \& Wong, 2012) and the universities' brand images (Ali-Choudhury, Bennett, \& Savani, 2009; Palmer, Koenig-Lewis, \& Asaad, 2016; Yuan, Liu, Luo, \& Yen, 2016). Therefore, the study of a model for advocacy modeling is considered very important in contributing to the literature, particularly in the education sectors. In this study, we examine the advocacy modelling of Indonesian Chinese students. We contribute to the literature in two ways. First, we add a new perspective to the existing body of literature on advocacy models in higher education institutions. Second, we contribute conceptually to the relationship between advocacy and trust, service quality, and image.

Our study focuses on the Chinese students of three private universities in Jakarta, Indonesia. Among others, Indonesian Chinese students are considered as the main consumers of most private universities in Indonesia. Private universities are interesting examples because they encounter a very high competition compared to public universities. Generally, public universities in Indonesia tend to have a higher brand image compared to private universities. Thus, in the process of selecting a university, students tend to put public universities in the first priority, then private universities in the next alternative in case the first option fails. In addition, a regional free trade enables foreign universities to open its classes in Indonesia cause higher competition encountered by private universities. A high number of alternatives as well as an access to high information cause private universities have to create the best advocacy model to attract prospective students and retain existing students to continue to pursue a higher level of education. In addition, we consider the relationship between service quality, image, trust and advocacy. Advocacy is the highest level of loyalty, according to (Griffin \& Herres, R., 2002). While other studies such as those conducted by (Heffernan, Wilkins, \& Butt, 2018; Pandey \& Deshwal, 2018; Pedro, Alves, \& Leitão, 2017; Weerasinghe \& Fernando, 2018) are focused on analyzing the relationship between experience, service quality, trust and reputation on student satisfaction and loyalty. In addition, this study only involves private universities whereas previous studies analyzed the general and state universities, so the relationships between the variables produced may be different. We develop and estimate structural equation modeling (SEM) to analyze the impact pathways. 


\section{LITERATURE REVIEW}

\section{Student advocacies}

A student advocacy is basically the highest level of the six levels of student loyalty, including: 1) suspects, 2) prospects, 3) disqualified prospects, 4) first-time consumers, 5) repeat students, 6) clients, and 7) advocates. Advocates are students who are willing to buy all goods or services offered as well as making purchases on a regular basis. Furthermore, they also provide recommendations on products or services and persuade others to make purchases of relevant products or services. In addition, advocates also talk about products or services and conduct marketing efforts as well as bring new students to the university (Griffin \& Herres, R., 2002). Student advocacy in general is the strength of the relationship between an individual's relative attitude and repeat patronage (Dick \& Basu, 1994). Student advocacy generates a high chance for repeated purchases of goods and services (Oliver, 1997). Moreover, (Javalgi \& Moberg, 1997) revealed that advocacy can be observed through two perspectives. First, the definition of advocacy in behavioral terms, usually based on the amount of purchase and measured by monitoring the frequency of purchase and easy to switch to other brands. Second, the definition of advocacy in attitudinal terms, that is the incorporation of consumer preferences and tendencies towards particular brands. Several factors expected to affect student advocacy are trust, satisfaction, image, costs, and service quality (Ball, Simões Coelho, \& Machás, 2004; Chai, Malhotra, \& Alpert, 2015; Daryanto et al., 2013; Dehghan, Dugger, Dobrzykowski, \& Balazs, 2014; Heffernan et al., 2018; Liu, Guo, \& Lee, 2011; Sharp \& Sharp, 1997; Weerasinghe \& Fernando, 2018). The following sections will specially examine the effect of trust, service quality, and image on the student advocacy.

\section{Student trust}

Trust is a credibility indicating the extent to which consumers believe that suppliers have the ability to carry out the activity effectively and reliably (Ganesan, 1994). Furthermore, trust is a psychological state that consists of the desire to receive an unpleasant circumstance which are based on a positive expectation of others (Colquitt, Scott, \& LePine, 2007; McShane \& Glinow, 2008). Furthermore, (Moriuchi \& Takahashi, 2016) argue that trust is a very important aspect due to the high level of uncertainty. Furthermore, there are some basic elements of student trust, namely integrity, competence, consistency, openness, and benevolence (Casaló, Flavián, \& Guinalíu, 2007; Mayer, Davis, \& Schoorman, 2011; Ridings, Gefen, \& Arinze, 2002; Robbins \& Judge, 2007). Finally, (Adler, 2001) enhances some aspects consisting of sources, direct interpersonal relationships, reputations, institutional contexts, individualism, systems, collectivities, attentions and goodwills as additional dimensions of student trust. Previous studies have proven that several factors affecting student trust are service quality, image, cost and satisfaction (C. Chen, 2006; Daryanto et al., 2013; Garbarino \& Lee, 2003; Heffernan et al., 2018; Jin, Park, \& Kim, 2008; Kantsperger \& Kunz, 2010; Keh \& Xie, 2009; Lin \& Ching Yuh, 2010; Sirdeshmukh, Singh, \& Sabol, 2002; Sultan \& Wong, 2012). 


\section{Images}

Image is an individual or company's reputation. Image can be interpreted as a set of beliefs, ideas and impressions about an object or persons who may be individuals or companies (Kotler, 2000; Newsom, Turk, \& Kruckeberg, 2006). In addition, (Bosch, J., Venter, E., Han, Y., \& Boshoff, 2006; Melewar \& Akel, 2005) outline the three main indicators of images, namely visual indicators, verbal, and behaviors. First, visual indicators relate to organizational aspects that can be directly seen by the eye. It may include organizational style, layout, employee appearance, brand, exterior, interior, cleanliness, lighting and others. Verbal indicators associate with respect to matters orally can be known by students or stakeholders, such as advertising, public discussion with stakeholders, and others. Finally, behavioral indicators associate with the management and output of an organization, for instance, are financial result, strategic position, good management, social responsibility, and others. Previous studies have indicated that image becomes a very important aspect of universities since the 1990s and it was influenced by alternatives created by prospective students (Kotler \& Fox, 1985). The main purpose of image for universities is to obtain the attraction and the advocacy of students. According to (Ali-Choudhury et al., 2009; Henseler, Ringle, \& Sinkovics, 2009). According to (Ali-Choudhury et al., 2009; Y.-C. Chen, 2017; Dehghan et al., 2014; Heffernan et al., 2018), brand images of universities is a manifestation that distinguishes a university with others, illustrate the capacity to satisfy the wants and needs of the students there and have a great potential to recruit prospective students.

\section{Service qualities}

Service quality is a concept that relates students' expectations before consuming goods and services and their perceptions after consuming those goods and services (Parasuraman, Zeithaml, \& Berry, 1985; Zeithaml, Berry, \& Parasuraman, 1990). In order to provide quality above consumers' expectations, institutions must understand what is expected by the consumers (Zeithaml et al., 1990). Previous empirical studies in educational institutions indicated that there were five dimensions of service quality, namely physical evidence, reliability, responsiveness, assurance, and empathy (Zeithaml et al., 1990). It is also demonstrated by (Abili, Narenji Thani, \& Afarinandehbin, 2012; Bahadori, Mousavi, Sadeghifar, \& Hagni, 2013; Chin Wei \& Sri Ramalu, 2011; Fitri \& Hasan, 2008; Galeeva, 2016; Leonnard, 2017; Zabed Ahmed \& Hossain Shoeb, 2009).

\section{FRAMEWORK}

Based on the literature reviews and the result of past relevant studies, it can be expected that service quality and image will have positive effects on satisfaction and trust, thus this implies on consumer loyalty. The constellation of causality between variables can be constructed into following research framework, as can be seen in the figure 1 below. 


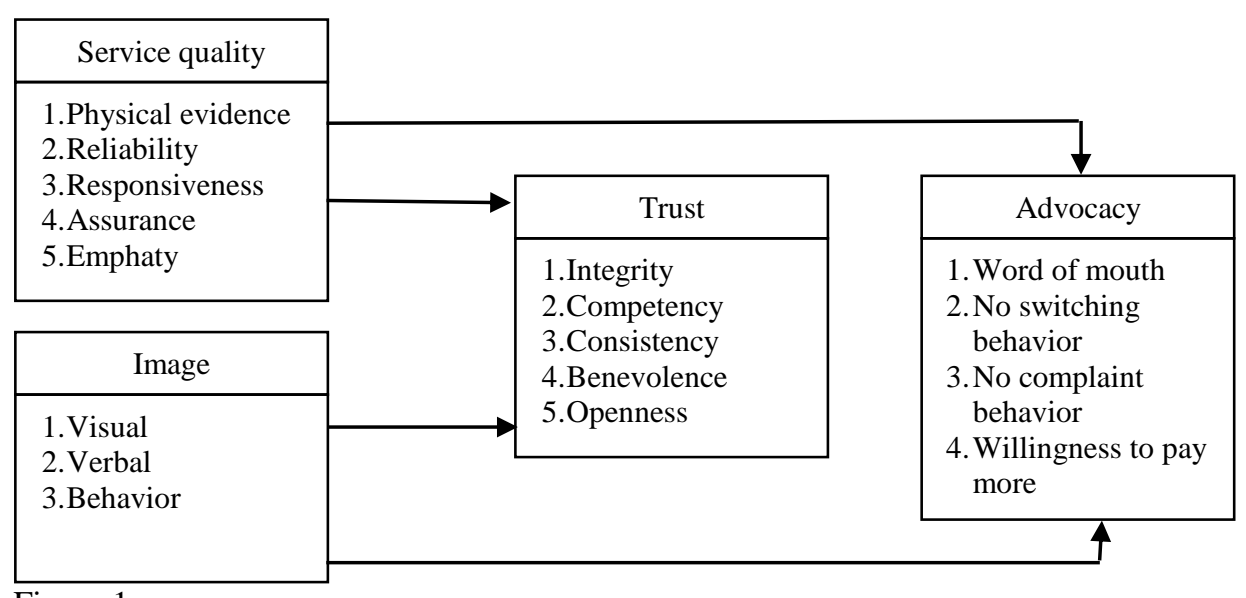

Figure 1

The proposed advocacy model of Indonesian Chinese students at private universities Jakarta

Therefore, the hypotheses to be examined in this study are:

H1: Service quality positively affects the trust of Indonesian Chinese students in private universities

H2: Image positively affects trust of Indonesian Chinese students in private universities

H3: Service quality positively affects advocacy of Indonesian Chinese students in private universities

H4: Image positively effects student advocacy of Indonesian Chinese students in private universities

H5: Trust positively affects student advocacy of Indonesian Chinese students in private universities

\section{METHOD}

\section{Measurement development}

A survey was carried out to examine the hypotheses. The main purpose of this study is to build the advocacy modeling of Indonesian Chinese students in private universities. Advocacy is measured by indicators of word of mouth, no switching behavior, no complaint behavior, and willingness to pay more (Zeithaml et al., 1990). Trust is measured by indicators of integrity, competency, consistency, benevolence, and openness (Mayer et al., 2011; Robbins \& Judge, 2007). Moreover, service quality is measured by indicators of physical evidence, reliability, responsiveness, assurance, and empathy (Zeithaml et al., 1990). Finally, images are measured by indicators of visual, verbal, and behavior (Daryanto et al., 2013). All of the measurements are obtained by using a 5-point Likert scale. 


\section{Sample and data collection}

The sample used in this study was 250 Chinese students from London School of Public Relations (LSPR), Jakarta, Indonesia through simple random sampling method. LSPR is one of the private universities in Indonesia, where the majority of students are Chinese students. The university consists of eight different study programs, including public relations, marketing, mass communication, visual communication and advertising design, performing art communication, corporate communication, marketing communication, and mass communication.

\section{Data analysis}

Data analysis was performed by employing Structural Equation Modeling Covariance Based (CBSEM) method and the Lisrel 8.8 software packages. The CBSEM uses a maximum likelihood function which works by minimizing the difference between covariance matrix formed from data with matrix covariance from the model prediction (Yamin \& Kurniawan, 2011). The use of this method is considered appropriate to illustrate the relationship between indicators with latent variables and latent variable relationships with other latent variables and large sample quantities. According to Hair et al (1998), the number of samples sufficient for CBSEM is between 100 to 200 samples or 5 to 10 times the number of parameters to be estimated. Stages of analysis using this method include: 1) conceptualizing model, 2) establishing flowchart, 3) model specification as well as measurement of the properties and number of parameters estimated, 4) identifying model, 5) estimating parameters, 6) testing fit model through RMSEA indicator , RMR, GFI, CFI, TLI, NFI, etc., and 7) cross-validation model (Ghozali, 2008).

\section{FINDINGS}

\section{Measurement model}

First, the model used in this study was evaluated by using confirmatory factor analysis (CFA) to ensure convergent validity and reliability. Most of the standardized loading factors for the constructs are greater than 0.50 and AVE values are above the critical level of $0.05(p<0.001)$ which indicating convergent validity was ensured. Moreover, all of C.R. Values are greater than the acceptable level of 0.70 with $p$-value $<0.001$ indicates that discriminant validity is achieved (Table 1). 
Table 1

CFA result for the measurement model

\begin{tabular}{|c|c|c|c|c|c|}
\hline \multirow{2}{*}{ Constructs } & \multirow{2}{*}{ Indicators } & \multicolumn{2}{|c|}{ Convergent validity } & \multirow{2}{*}{$\begin{array}{l}\text { Measurement } \\
\text { Error }\end{array}$} & \multirow{2}{*}{$\begin{array}{l}\text { Discriminant } \\
\text { validity } \\
\mathrm{CR}\end{array}$} \\
\hline & & $\begin{array}{l}\text { Standardized } \\
\text { loading factor }\end{array}$ & AVE & & \\
\hline \multirow{5}{*}{$\begin{array}{l}\text { Service } \\
\text { quality } \\
(\mathrm{X} 1)\end{array}$} & $\begin{array}{l}\text { Physical } \\
\text { evidence }\end{array}$ & 0.740 & \multirow[t]{5}{*}{0.535} & 0.460 & \multirow[t]{5}{*}{0.849} \\
\hline & Reliability & 0.820 & & 0.330 & \\
\hline & Responsiveness & 0.830 & & 0.310 & \\
\hline & Assurance & 0.640 & & 0.600 & \\
\hline & Emphaty & 0.600 & & 0.640 & \\
\hline \multirow{3}{*}{$\begin{array}{l}\text { Image } \\
(\mathrm{X} 2)\end{array}$} & Visual & 0.630 & \multirow[t]{3}{*}{0.597} & 0.600 & \multirow[t]{3}{*}{0.813} \\
\hline & Verbal & 0.840 & & 0.300 & \\
\hline & Behavior & 0.830 & & 0.310 & \\
\hline \multirow{5}{*}{$\begin{array}{l}\text { Trust } \\
\text { (Y1) }\end{array}$} & Integrity & 0.800 & \multirow[t]{5}{*}{0.666} & 0.350 & \multirow[t]{5}{*}{0.909} \\
\hline & Competency & 0.840 & & 0.300 & \\
\hline & Consistency & 0.790 & & 0.380 & \\
\hline & Benevolence & 0.860 & & 0.250 & \\
\hline & Openness & 0.790 & & 0.380 & \\
\hline \multirow{4}{*}{$\begin{array}{l}\text { Advocacy } \\
\text { (Y2) }\end{array}$} & World of mouth & 0.810 & \multirow[t]{4}{*}{0.464} & 0.340 & \multirow[t]{4}{*}{0.769} \\
\hline & $\begin{array}{l}\text { No switching } \\
\text { behavior }\end{array}$ & 0.800 & & 0.360 & \\
\hline & $\begin{array}{l}\text { No complaint } \\
\text { behavior }\end{array}$ & 0.560 & & 0.680 & \\
\hline & $\begin{array}{l}\text { Willingness to } \\
\text { pay more }\end{array}$ & 0.500 & & 0.750 & \\
\hline
\end{tabular}

The goodness of fit indices of overall model indicates that in general, there is an acceptable fit between the model and data (Table 2). The absolute fit indices signify the root mean square error of approximation (RMSEA) and the root mean square residual $(\mathrm{RMR})$ values are greater than the recommended cutoff values $(\mathrm{RMSEA}=0.071 ; \mathrm{RMR}$ $=0.020)$. The incremental fit indices signify the normed fit index (RFI), the incremental fit index (IFI), and the comparative fit index (CFI) values are greater than the recommended cutoff values $(\mathrm{NFI}=0.97 ; \mathrm{RFI}=0.97$; IFI $=0.99 ; \mathrm{CFI}=0.99)$. Furthermore, the parsimonious fit indices also signify the parsimony normed fit index (PNFI), the parsimony goodness of fit index (PGFI), and the CAIC (AIC < saturated AIC) model has met the acceptable levels $(\mathrm{PNFI}=0.81$; PGFI $=0.66$; CAIC $(515.52<$ 997.78). 
Table 2

Goodness of fit indices of the research model

\begin{tabular}{ll}
\hline Fit index & Overall model fit \\
\hline Absolute fit indices & \\
\hline $\mathrm{X}^{2}$ & 0.000 \\
\hline RMSEA & 0.071 \\
\hline RMR & 0.020 \\
\hline Incremental fit indices & \\
\hline NFI & 0.970 \\
\hline RFI & 0.970 \\
\hline IFI & 0.990 \\
\hline CFI & 0.990 \\
\hline Parsimonius fit indices & \\
\hline PNFI & 0.810 \\
\hline PGFI & 0.660 \\
\hline CAIC & $515.52<997.78$ \\
\hline
\end{tabular}

The results of the hypothesis testing of the research model are denoted in Table 3 . The four standardized coefficients of the hypothesis $(\mathrm{H} 1, \mathrm{H} 2, \mathrm{H} 3, \mathrm{H} 5)$ have positive and significant values. The fourth hypothesis has a positive value, but not significant. Both service qualities (H3) and trust (H5) affect the advocacy of Chinese students with a greater influence of trust (coeff. $=0.64)$ than service quality (coeff. $=0.27$ ). This relationship is consistent with the findings of Sharp \& Sharp (1997) and Liu et al. (2011). Furthermore, service quality (H1) and image (H2) are also known to positively affect trust. Service quality has a greater effect $($ coeff. $=0.51)$ images $($ coeff. $=0.47)$.

Table 3

Path coefficient of the research model

\begin{tabular}{|c|c|c|c|c|c|}
\hline Hypotheses & Path & Standardized loading $(\beta)$ & t-values & Results & \\
\hline $\mathrm{H} 1$ & $\mathrm{X} 1$->Y1 & 0.51 & $5.17 * * *$ & Supported & \\
\hline $\mathrm{H} 2$ & & & $\begin{array}{ll}\mathrm{X} 2 & 0.47 \\
- & \\
>\mathrm{Y} 1 & \end{array}$ & $4.78 * * *$ & Supported \\
\hline $\mathrm{H} 3$ & $\mathrm{X} 1->\mathrm{Y} 2$ & 0.27 & $2.39 * * *$ & & Supported \\
\hline $\mathrm{H} 4$ & $\mathrm{X} 2$->Y2 & 0.14 & 1.22 & & Unsupported \\
\hline H5 & Y1 ->Y2 & 0.64 & $4.36 * * *$ & & Supported \\
\hline
\end{tabular}

In addition to the hypothesis testing above, the effect of trust as a mediating variable increases the total effect of service quality on advocacy with the value of 0.59 . The total effect is greater than the direct effect of service quality on advocacy (coeff. $=0.27$ ). The same condition is developed on the total effect of image on advocacy where the presence of trust increases the total effects with the value of 0.44 . The effect is greater than the direct effect of image on advocacy (coeff.= 0.14) (Table 4). The finding indicates that consumer trust is able to increase the advocacy with the total effect greater than the direct effect of each variable. The finding is also supported by the greatest direct effect of trust on advocacy compared to other variables. Therefore, private 
universities need to give a high attention in increasing consumer trust to increase advocacy of their students. Besides, consumer trust will indirectly lead to advocacy through service quality and image.

Table 4

Direct, indirect, and total effects

\begin{tabular}{lllllllllllll}
\hline & \multicolumn{3}{c}{ Service quality } & \multicolumn{3}{c}{ Image } & \multicolumn{3}{c}{ Trust } & \multicolumn{2}{c}{ Advocacy } \\
\hline & DE & IE & TE & DE & IE & TE & DE & IE & TE & DE & IE & TE \\
\hline Service quality & - & - & - & - & - & - & $0.51^{* * *}$ & - & 0.51 & $0.27^{* * *}$ & 0.32 & 0.59 \\
\hline Image & - & - & - & - & - & - & $0.47 * * *$ & - & 0.47 & $0.14^{* * *}$ & 0.30 & 0.44 \\
\hline Trust & - & - & - & - & - & - & - & - & - & 0.64 & - & 0.64 \\
\hline Advocacy & - & - & - & - & - & - & - & - & - & - & - & - \\
\hline Noter & DE & Direct effects; IE- Indirect & effects; TE- Total effects & & & & &
\end{tabular}

Ade: $\quad$ DE $=$ Direct effects; $\mathrm{IE}=$ Indirect effects; $\mathrm{TE}=$ Total effects

Overall, the research output diagram is denoted in Figure 3. The model is validated by following recommendations of (Daryanto et al., 2013; Mayer et al., 2011; Parasuraman et al., 1985; Robbins \& Judge, 2007).

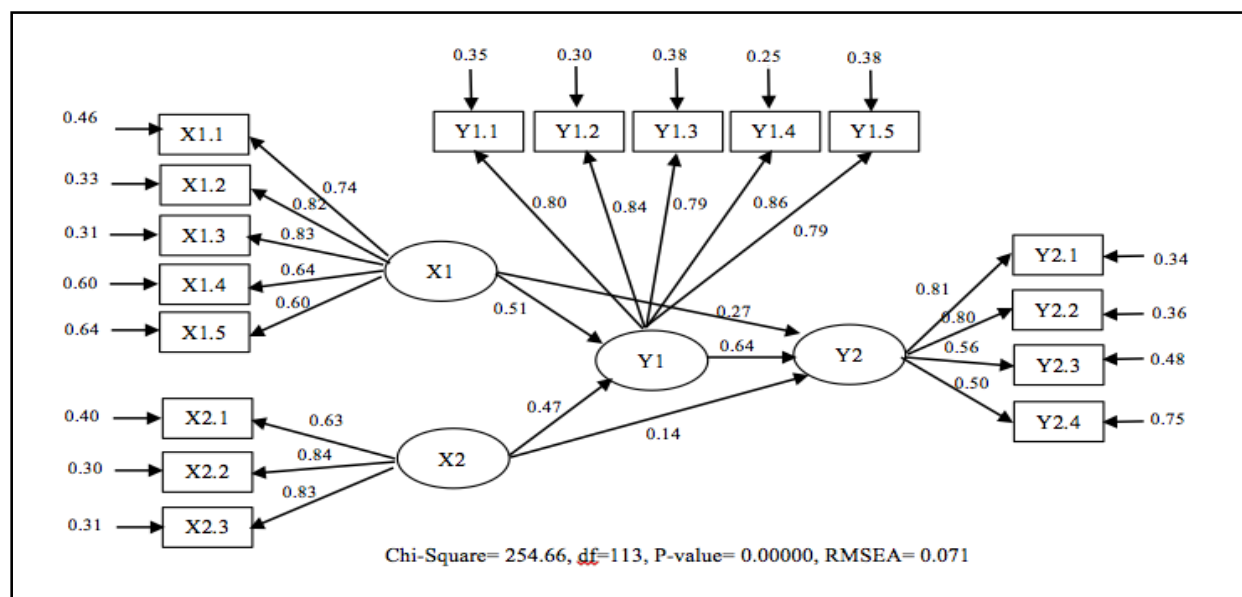

Figure 2

Research output diagram

The findings in figure 3 above indicated that the effect of service quality (coeff. $=0.51$ ) on student trust is higher than the effect of image (coeff.=0.47). There are five indicators used to measure service quality of private universities in this study, namely physical evidence, reliability, responsiveness, assurance, and empathy. Of the five indicators, responsiveness (coeff. $=0.83$ ) has the highest effect, followed by reliability (coeff. $=0.82)$, physical evidence (coeff. $=0.74)$, assurance (coeff. $=0.64)$, and empathy (coeff. $=0.60)$. Responsiveness according to (Zeithaml et al., 1990) is the readiness and the speed to serve and respond to consumers. This indicator is considered the most important indicator for students in assessing the service quality of the universities. Moreover, service quality not only affects student trust directly, but also directly affects student advocacy. Conversely, images do not significantly affect student advocacy directly. The indicator of images that has the highest effect is behavior (coeff. $=0.84$ ), 
followed by verbal (coeff. $=0.83$ ) and visual (coeff. $=0.63)$. These results indicate that in assessing the university image, students are dependent not only on what they see and hear, but also how universities behave towards students and internal human resources. Finally, student trust significantly affects student advocacy. There are five indicators used to measure student trust, namely integrity, competency, consistency, benevolence, and openness. Of the five indicators, benevolence has the highest influence (coeff. = 0.86 ), followed by competency (coeff. $=0.80$ ), integrity (coeff. $=0.79$ ), consistency (coeff. $=0.79)$, and openness $($ coeff $=0.79)$. Benevolence is the willingness of the university to help and provide solutions to student problems. The higher the university's attention to this indicator, the higher the effect that the student trust will bring to the student advocacy.

\section{DISCUSSION}

The empirical evidence from our study indicates that the factors that affect advocacy of Chinese students are service quality, image, and trust. Those factors are differentiated into factors that provide direct effects and indirect effects. Findings from our study suggest that consumer trust has the greatest direct effect over the other factors. This finding supports (Ball et al., 2004; Y.-C. Chen, 2017; Dehghan et al., 2014; Heffernan et al., 2018) which states that consumer trust is a powerful predictor of advocacy in higher educational institutions and universities. Consumer trust is generated from evaluation process and emotional response when students interact directly with private universities. The existence of high service quality and high image of private universities will directly increase student trusts that will ultimately lead to consumer advocacy. This finding is consistent with (C. Chen, 2006; Daryanto et al., 2013; Garbarino \& Lee, 2003; Heffernan et al., 2018; Jin et al., 2008; Kantsperger \& Kunz, 2010; Keh \& Xie, 2009; Sirdeshmukh et al., 2002; Sultan \& Wong, 2012; Usyd, Daryanto, Sukandar, \& Yusuf, 2013). Students who feel trust with private universities will become advocates for new students who want to choose the universities to continue their higher educations. This is also supported by empirical evidences in the previous section. In addition, the direct impact of service quality on student advocacy is consistent with (Daryanto et al., 2013; Pedro et al., 2017; Weerasinghe \& Fernando, 2018).These results indicate a very high service quality role in improving student advocacy. The success of private universities to provide service quality in accordance with the expectations of students will make them loyal to the universities and become an effective promotional tool in attracting other prospective students.

These findings lead to several managerial implications. First, it will help managers and leaders of private universities to understand the key factors affecting advocacy of their students. As the powerful effect of trust on student advocacy, managers and leaders of private universities should emphasize on building consumer trusts, especially through service quality that has a greater influence. Building service quality should be carried out through paying a great attention to aspects of responsiveness, reliability, and physical evidence. These aspects include the provision of fast responses and quick complaint handlings (responsiveness), high administrative and academic services to students (reliability), and provision of adequate university facilities (physical evidence). 
This finding is supported by (Bahadori et al., 2013; Chin Wei \& Sri Ramalu, 2011; Fitri \& Hasan, 2008; Pedro et al., 2017; Weerasinghe \& Fernando, 2018; Zeithaml et al., 1990). Building image should emphasize on behaviors and verbal aspects. Finally, university visibility can be performed through advertisements, activities and scientific publications while the improvement of behavioral aspects is performed through the high quality of leaderships and university outputs (Bosch, J., Venter, E., Han, Y., \& Boshoff, 2006; Daryanto et al., 2013; Melewar \& Akel, 2005).

\section{CONCLUSION}

According to the empirical evidences, trust has a powerful positive effect on advocacy of Chinese students in private universities in Indonesia. Moreover, service quality and image also have positive effects on trust and advocacy. The total influence of these two variables increases with the existence of trust as a mediating variable. The results of this study contribute well to the literature on factors affecting student advocacy in private universities. In addition, for managers and leaders of private universities, focusing on improving the service quality and image of the university, will have a major impact on loyalty of students to complete their education, have a high opportunity to pursue higher education at the same university, and disseminate positive information about universities to the public. However, this study has several limitations. First, the study is limited to the three key variables and their pathways. In addition, the object of this study is limited to private universities in Greater Jakarta. Further research is suggested to be conducted at state universities or private universities in other cities. The relationships generated between variables are possibly different.

\section{REFERENCES}

Abdullah, N., \& Mohamad, N. (2016). University Recreational Facilities Service Quality and Students' Physical Activity Level. Procedia - Social and Behavioral Sciences, 224(August 2015), 207-212. https://doi.org/10.1016/j.sbspro.2016.05.443

Abili, K., Narenji Thani, F., \& Afarinandehbin, M. (2012). Measuring university service quality by means of SERVQUAL method. Asian Journal on Quality, 13(3), 204-211. https://doi.org/10.1108/15982681211287766

Adler, P. S. (2001). Market, Hierarchy, and Trust: The Knowledge Economy and the Future of Capitalism. Organization Science, 12(2), 215-234. https://doi.org/10.1287/orsc.12.2.215.10117

Alemu, A. M., \& Cordier, J. (2017). Factors influencing international student satisfaction in Korean universities. International Journal of Educational Development, 57(August), 54-64. https://doi.org/10.1016/j.ijedudev.2017.08.006

Ali-Choudhury, R., Bennett, R., \& Savani, S. (2009). University marketing directors' views on the components of a university brand. International Review on Public and Nonprofit Marketing, 6(1), 11-33. https://doi.org/10.1007/s12208-008-0021-6

Arif, S., Ilyas, M., \& Hameed, A. (2013). Student satisfaction and impact of leadership in private universities. The TQM Journal, 25(4), 399-416. 


\section{https://doi.org/10.1108/17542731311314881}

Bahadori, M. K., Mousavi, S. M., Sadeghifar, J., \& Hagni, M. (2013). Reliability and Performance of SEVQUAL Survey in Evaluating Quality of Medical Education Services, 2(1), 39-44.

Ball, D., Simões Coelho, P., \& Machás, A. (2004). The role of communication and trust in explaining customer loyalty. European Journal of Marketing, 38(9/10), 1272-1293. https://doi.org/10.1108/03090560410548979

Bharadwaj, S. G., Varadarajan, P. R., \& Fahy, J. (1993). Competitive Advantage in Service Industries : A Conceptual Model. Journal of Marketing, 57(4), 83-99.

Bosch, J., Venter, E., Han, Y., \& Boshoff, C. (2006). The impact of brand identity on the perceived brand image of a merged higher education institution: Part two. Management Dynamics, 15, 36-54.

Bryła, P. (2015). Self-reported Effects of and Satisfaction with International Student Mobility: A Large-scale Survey among Polish Former Erasmus Students. Procedia Social and Behavioral Sciences, 191, 2074-2082. https://doi.org/10.1016/j.sbspro.2015.04.248

Casaló, L., Flavián, C., \& Guinalíu, M. (2007). The impact of participation in virtual brand communities on consumer trust and loyalty: The case of free software. Online Information Review, 31(6), 775-792. https://doi.org/10.1108/14684520710841766

Chai, J. C. Y., Malhotra, N. K., \& Alpert, F. (2015). A two-dimensional model of trustvalue-loyalty in service relationships. Journal of Retailing and Consumer Services, 26, 23-31. https://doi.org/10.1016/j.jretconser.2015.05.005

Chen, C. (2006). Identifying Significant Factors Influencing Consumer Trust in an Online Travel Site. Information Technology \& Tourism, 8(3), 197-214. https://doi.org/10.3727/109830506778690849

Chen, Y.-C. (2017). Article information: International Journal of Educational Management, 31(7), 973-985. https://doi.org/http://dx.doi.org/10.1108/MRR-09-20150216

Cheok, M. L., \& Wong, S. L. (2015). Predictors of E-Learning Satisfaction in Teaching and Learning for School Teachers: A Literature Review. International Journal of Instruction, 8(1), 75-90. https://doi.org/10.12973/iji.2015.816a

Chin Wei, C., \& Sri Ramalu, S. (2011). Students Satisfaction towards the University: Does Service Quality Matters? International Journal of Education, 3(2), 1-15. https://doi.org/10.5296/ije.v3i2.1065

Chui, T. B., Ahmad, M. S. bin, Bassim, F. binti A., \& Zaimi, N. binti A. (2016). Evaluation of Service Quality of Private Higher Education Using Service Improvement Matrix. Procedia - Social and Behavioral Sciences, 224(August 2015), 132-140. https://doi.org/10.1016/j.sbspro.2016.05.417 
Colquitt, J. A., Scott, B. A., \& LePine, J. A. (2007). Trust, Trustworthiness, and Trust Propensity: A Meta-Analytic Test of Their Unique Relationships With Risk Taking and Job Performance. Journal of Applied Psychology, 92(4), 909-927. https://doi.org/10.1037/0021-9010.92.4.909

Daryanto, H. K. S., Sukandar, D., \& Yusuf, E. Z. (2013). The Loyalty Model of Private University Student, 7(1), 55-68. https://doi.org/https://doi.org/10.21632/irjbs.7.1.55-68

Dehghan, A., Dugger, J., Dobrzykowski, D., \& Balazs, A. (2014). The antecedents of student loyalty in online programs. International Journal of Educational Management, 28(1), 15-35. https://doi.org/10.1108/IJEM-01-2013-0007

Dick, A. S., \& Basu, K. (1994). Customer Loyalty: Toward an Integrated Conceptual Framework. Jounal of the Academy of Marketing Science, 22, 99-113.

El-Said, O. A., \& Fathy, E. A. (2015). Assessing university students' satisfaction with on-campus cafeteria services. Tourism Management Perspectives, 16, 318-324. https://doi.org/10.1016/j.tmp.2015.09.006

Fitri, H., \& Hasan, A. (2008). Service Quality and Student Satisfaction : A Case Study at Private Higher Education Institutions. International Business Research, 1(3), 163-175. https://doi.org/10.5539/ibr.v1n3p163

Galeeva, R. B. (2016). SERVQUAL application and adaptation for educational service quality assessments in Russian higher education. Quality Assurance in Education Quality Assurance in Education Iss, 24(3), 244-258. https://doi.org/10.1108/QAE-112016-0078

Ganesan, S. (1994). Determinants of Long-Term in Buyer-Seller Orientation Relationships. The Journal of Marketing, 58(April), 1-19. https://doi.org/10.2307/1252265

Garbarino, E., \& Lee, O. F. (2003). Dynamic Pricing in Internet Retail: Effects on Consumer Trust. Psychology and Marketing, 20(6), 495-513. https://doi.org/10.1002/mar.10084

Ghozali, I. (2008). Structural equation modeling: teori, konsep, dan aplikasi dengan Program Lisrel 8.80. Badan Penerbit Universitas Diponegoro.

Giner, G. R., \& Peralt Rillo, A. (2016). Structural equation modeling of co-creation and its influence on the student's satisfaction and loyalty towards university. Journal of Computational and Applied Mathematics, 291, 257-263. https://doi.org/10.1016/j.cam.2015.02.044

Gobena, G. A. (2018). Factors Affecting In- Service Teachers Motivation: Its Implication to Quality of Education, 11(3), 163-178.

Griffin, J., \& Herres, R., T. (2002). Customer Loyalty: How to Earn It, How to Keep It.

Heffernan, T., Wilkins, S., \& Butt, M. M. (2018). Transnational higher education: The importance of institutional reputation, trust and student-university identification in 
international partnerships. International Journal of Educational Management, 32(2), 227-240. https://doi.org/10.1108/IJEM-05-2017-0122

Henseler, J., Ringle, C. M., \& Sinkovics, R. R. (2009). The use of Partial Least Squares Path Modeling in International Marketing. Advances in International Marketing. https://doi.org/10.1016/0167-8116(92)90003-4

Hussain, I., Rahman, S. U., Zaheer, A., \& Saleem, S. (2016). Integrating factors influencing consumers' halal products purchase: Application of theory of reasoned action. Journal of International Food and Agribusiness Marketing. https://doi.org/10.1080/08974438.2015.1006973

Javalgi, R., \& Moberg, C. R. (1997). Service loyalty: implications for service providers. Journal of Services Marketing, 11(3), 165-179. https://doi.org/10.1108/08876049710168663

Jin, B., Park, J. Y., \& Kim, J. (2008). Cross-cultural examination of the relationships among firm reputation, e-satisfaction, e-trust, and e-loyalty. International Marketing Review, 25(3), 324-337. https://doi.org/10.1108/02651330810877243

Kantsperger, R., \& Kunz, W. H. (2010). Consumer trust in service companies: a multiple mediating analysis. Managing Service Quality: An International Journal, 20(1), 4-25. https://doi.org/10.1108/09604521011011603

Keh, H. T., \& Xie, Y. (2009). Corporate reputation and customer behavioral intentions: The roles of trust, identification and commitment. Industrial Marketing Management, 38(7), 732-742. https://doi.org/10.1016/j.indmarman.2008.02.005

Kotler, P. (2000). Marketing Management: The Millennium Edition. Prentice Hall.

Kotler, P., \& Fox, Karen, F., A. (1985). Strategic Marketing for Educational Institutions. Prentice-Hall.

Leonnard. (2017). Measuring Grocery Stores Service Quality in Indonesia : a Retail Service Quality Scale, 26, 32-44.

Lin, L. Y., \& Ching Yuh, C. Y. (2010). The influence of corporate image, relationship marketing, and trust on purchase intention: the moderating effects of word $\square$ of $\square$ mouth. Tourism Review, 65(3), 16-34. https://doi.org/10.1108/16605371011083503

Liu, C. T., Guo, Y. M., \& Lee, C. H. (2011). The effects of relationship quality and switching barriers on customer loyalty. International Journal of Information Management, 31(1), 71-79. https://doi.org/10.1016/j.ijinfomgt.2010.05.008

Mayer, R. C., Davis, J. H., \& Schoorman, F. D. (2011). Model of Trust. Academy of Management, 20(3), 709-734. https://doi.org/10.5465/AMR.1995.9508080335

McShane, S., \& Glinow, M. Von. (2008). Organizational Behavior 8th Edition. McGraw-Hill Higher Education.

Melewar, T. C., \& Akel, S. (2005). The role of corporate identity in the higher 
education sector: A case study. Corporate Communications, 10(1), 41-57. https://doi.org/10.1108/13563280510578196

Moriuchi, E., \& Takahashi, I. (2016). Satisfaction trust and loyalty of repeat online consumer within the Japanese online supermarket trade. Australasian Marketing Journal, 24(2), 146-156. https://doi.org/10.1016/j.ausmj.2016.02.006

Newsom, D., Turk, J., \& Kruckeberg, D. (2006). This is PR: The Realities of Public Relations (Thomson Advantage Books).

Oliver, R. L. (1997). Satisfaction: A Behavioral Perspective on the Consumer. Journal of Consumer Marketing. https://doi.org/10.1139/h11-134

Palmer, A., Koenig-Lewis, N., \& Asaad, Y. (2016). Brand identification in higher education: A conditional process analysis. Journal of Business Research, 69(8), 30333040. https://doi.org/10.1016/j.jbusres.2016.01.018

Pandey, S., \& Deshwal, P. (2018). The Influence of Medical Course Experience on Satisfaction, Loyalty, and Word-Of-Mouth in Indian Medical Colleges. Procedia Computer Science, 132, 84-91. https://doi.org/10.1016/j.procs.2018.05.165

Parasuraman, A., Zeithaml, V. A., \& Berry, L. L. (1985). A Conceptual Model of Service Quality and Its Implications for Future Research. Journal of Marketing. https://doi.org/10.2307/1251430

Pedro, E. D. M., Alves, H., \& Leitão, J. (2017). Article information : Does the quality of academic life mediate the satisfaction, loyalty and.

Ridings, C. M., Gefen, D., \& Arinze, B. (2002). Some antecedents and effects of trust in virtual communities. The Journal of Strategic Information Systems, 11(3-4), 271-295. https://doi.org/10.1016/S0963-8687(02)00021-5

Robbins, S. P., \& Judge, T. A. (2007). Organizational Behavior (12th ed.). Upper Saddle River, NJ: Prentice Hall.

Sharp, B., \& Sharp, A. (1997). Loyalty programs and their impact on repeat-purchase loyalty patterns. International Journal of Research in Marketing, 14(5), 473-486. https://doi.org/10.1016/S0167-8116(97)00022-0

Sirdeshmukh, D., Singh, J., \& Sabol, B. (2002). Consumer Trust, Value, and Loyalty in Relational Exchanges. Journal of Marketing, 66(1), 15-37. https://doi.org/10.1509/jmkg.66.1.15.18449

Sultan, P., \& Wong, H. Y. (2012). Service quality in a higher education context: An integrated model. Asia Pacific Journal of Marketing and Logistics, 24(5), 755-784. https://doi.org/10.1108/13555851211278196

Susilo, W. H. (2016). An Impact of Behavioral Segmentation to Increase Consumer Loyalty: Empirical Study in Higher Education of Postgraduate Institutions at Jakarta. Procedia - Social and Behavioral Sciences, 229, 183-195. https://doi.org/10.1016/j.sbspro.2016.07.128 
Usyd, Daryanto, H. K. S., Sukandar, D., \& Yusuf, E. Z. (2013). The loyalty model model of private university student Study Case : STIKOM London School of Public Relation. International Journal of Information Technology and Business Management, 20(1), 70-89.

Weerasinghe, I. M. S., \& Fernando, R. L. S. (2018). Critical factors affecting students' satisfaction with higher education in Sri Lanka. Quality Assurance in Education (Vol. 26). https://doi.org/10.1108/QAE-04-2017-0014

Yamin, S., \& Kurniawan, H. (2011). PLS path modeling. Generasi Baru Mengolah Data Penelitian dengan Partial Least Square Path Modeling: Aplikasi dengan Software XLSTAT, SmartPLS dan Visual PLS.

Yuan, R., Liu, M. J., Luo, J., \& Yen, D. A. (2016). Reciprocal transfer of brand identity and image associations arising from higher education brand extensions. Journal of Business Research, 69(8), 3069-3076. https://doi.org/10.1016/j.jbusres.2016.01.022

Zabed Ahmed, S. M., \& Hossain Shoeb, Z. (2009). Measuring service quality of a public university library in Bangladesh using SERVQUAL. Performance Measurement and Metrics, 10(1), 17-32. https://doi.org/10.1108/14678040910949666

Zedda, M., Bernardelli, S., \& Maran, D. A. (2017). Students' Satisfaction with the Group Work Method and its Performance Evaluation: A survey in an Italian University. International Journal of Instruction, 10(3), 1-14. https://doi.org/10.12973/iji.2017.1031a

Zeithaml, V. A., Berry, L. L., \& Parasuraman, A. (1990). Delivering Quality Service: Balancing Student Perceptions and Expectation. The Free Press. 